\title{
Determining Plant-available Water of Woody Ornamentals in Containers In Situ During Production
}

\author{
Richard C. Beeson ${ }^{1}$ \\ University of Florida, MREC, 2725 South Binion Road, Apopka, FL 32703
}

Additional index words. irrigation management, container production, nursery production, precision irrigation, substrate water relations

\begin{abstract}
In nursery production, small root balls are transplanted into larger containers and grown for sale or further transplanting into still larger containers. When a root ball is smaller than a container, the amount of plant-available water (PAW) is initially limited to that of the original root ball. With growth, roots colonize new substrate and thereby increase the volume of water available to a shoot. Because of hydraulic gradients in container substrates, PAW is not linearly proportional to the volume of substrate occupied by roots. To practice precision irrigation in nursery production, it is important to know the extent of PAW and how it changes with growth. A method is detailed that calculates in situ PAW in containers based on changes in actual evapotranspiration while irrigation is withheld. The method is applied under field conditions and requires only daily mass loss measurements and corresponding reference evapotranspiration. An example of how PAW changes during production from rooted cuttings to marketable size plants is provided.
\end{abstract}

Commercially acceptable growth rates of woody ornamental nursery stock can be achieved using managed allowed deficits, i.e., deficit irrigations, of $20 \%$ to $40 \%$ plantavailable water (PAW) before initiating irrigation (Beeson, 2006; Welsh and Zajicek, 1993). Deficit irrigation can reduce irrigation frequency (Beeson, 2006), thereby reducing nursery water runoff and energy consumption. Using deficit irrigation for container production of nursery stock is especially valuable for water conservation when rain occurs, because rainfall can account for part or all of a plant's daily evapotranspiration. Rainfall is more effective in penetrating plant canopies than overhead sprinkler irrigation (Beeson and Yeager, 2003), being nearly $100 \%$ efficient and more uniform than overhead irrigation. Therefore, less rainfall is required to return a container to capacity than overhead irrigation. However, to apply deficit irrigation strategies, or determine how much rainfall is sufficient and when additional supplemental irrigation is required, knowledge of PAW is necessary. This is especially critical during the early stages of plant production, when roots have not completely colonized a container's volume. At this stage, the lower substrate may be at or near $100 \%$ container capacity, whereas PAW may be critically low within the actual root ball.

PAW can be found by first recording the mass of a plant/container with a saturated substrate from which excess water has been allowed to drain. The plant is then allowed to

Received for publication 9 Apr. 2007. Accepted for publication 1 July 2007.

${ }^{1}$ To whom reprint requests should be addressed; e-mail rcbeeson@ufl.edu. transpire until wilted. PAW is calculated as the difference in mass between saturated and wilted conditions (Beardsell et al., 1979b). For a container with a full root ball, total PAW (PAW Total ) can be consistent across species if the container size and substrate are identical (Beeson, 2006)

Although a similar approach can be applied to plants growing in a container in which roots have not yet filled the container volume, there are drawbacks. Stressing a plant to physical wilt can cause leaf drop in some species and may stunt shoot growth after stress is relieved. Because roots are growing into uncolonized substrate, volume of PAW continues to increase, delaying shoot wilt and therefore skewing the estimate of PAW. In situations in which root colonization of a substrate is not complete, PAW can be termed effective PAW (PAW $\mathrm{Effec}$ ). This skewing is especially prominent when evaporative demand is low during the drying period. For evergreen species that are dormant or that have rigid leaves and stems, determining the point of plant wilt can be difficult. Applying supplemental irrigation that exceeds the PAW Effec $_{\text {is }}$ is waste of water and can lead to excessive leaching of nutrients. Overestimating $\mathrm{PAW}_{\mathrm{Effec}}$ would result in underirrigation and perhaps commercially unacceptable growth rates. Precision irrigation of container plants requires an accurate estimate of PAW $\mathrm{Effec}_{\text {. }}$

An alternative for plants that have not colonized a container's volume is to determine root ball volume relative to total container volume. Volume of a developing root system can be easily determined by water displacement. One could then calculate a percentage of container volume and infer $\mathrm{PAW}_{\text {Effec }}$ if PAW $\mathrm{P}_{\text {Total }}$ is known. However, water distribution in container substrates varies by substrate composition (Beardsell et al., 1979a; Bilderback et al., 1982; Richards et al., 1986), container size (Bunt, 1976), and container configuration (Bilderback and Fonteno, 1987; Davis et al., 1964; Spooner, 1974; Williams, 1978). In general, hydraulic gradients are established by opposing forces of capillary rise from water interacting with pores within a substrate and gravity pulling water to the bottom of a container (Bilderback and Fonteno, 1987). Although gradients can be determined, they vary with substrate composition and root ball height (Bilderback and Fonteno, 1987). Thus, simple determination of percent root ball volume of a developing root system in a container cannot accurately predict $\mathrm{PAW}_{\mathrm{Effec}}$, even if PAW $_{\text {Total }}$ is known.

With increasing demands being placed on landscape nurseries to reduce ground or watershed water withdraws for irrigation, and to reduce nutrients in runoff water, nurseries should begin practicing precision irrigation, applying only as much water as needed, when needed. To do so, knowledge of PAW accessible at a given stage of growth is needed to accurately apply deficit irrigation strategies. Previously, there has been no research in this area for container-grown nursery crops. Objectives of the research presented here were to: 1) verify a nondestructive method for determining PAW in containers in situ, 2 ) verify the method was valid across plant species, and 3) to examine relationships between PAW and canopy variables among species. To demonstrate the use of this method, a partial data set from an experiment to quantify water use of Viburnum odoratissimum was used to calculate $\mathrm{PAW}_{\mathrm{Effec}}$ and $\mathrm{PAW}_{\text {Total }}$ during production from rooted cuttings to market-sized plants.

\section{Materials and Methods}

In mid-Oct. 1997, four plants of five species of woody ornamentals were selected and placed in an open-sided, single-layer clear polyethylene-covered shelter to exclude rain fall. Species were selected for their range of plant size, representation in nursery production, and commercial reputation for drought tolerance or intolerance in containers. Species selected, as ranked from least to most drought-tolerant, were Viburnum odoratissimum, Ligustrum japonica, Photinia $\times$ fraseri, Elaeagnus pungens, and Rhaphiolepis indica. Each plant had been grown to marketable size in an 11.4-L black polyethylene container (Lerio Corp., Kissimmee, FL) at the Central Florida Research and Education Center in Sanford, FL during the previous 2 years. Substrate consisted of $64 \%$ composted pine bark, 27\% Florida sedge peat, and $9 \%$ coarse sand by volume amended with $0.88 \mathrm{~kg} \cdot \mathrm{m}^{-3}$ micronutrients (Peter's Fritted Trace Elements; Scotts Company, Marysville, $\mathrm{OH}$ ) and $2.9 \mathrm{~kg} \cdot \mathrm{m}^{-3}$ dolomite limestone blended by a commercial vendor (Sunrise Landscape, Apopka, FL). Each plant was placed in a suspension lysimeter 
(Beeson, 2006) and suspended $\approx 5 \mathrm{~cm}$ above the ground. Lysimeters were spaced such that there was $\approx 1.5 \mathrm{~m}$ between plants. Briefly, a lysimeter consisted of a $22.7-\mathrm{kg}$ load cell (SSM-50; Interface, Scottsdale, AZ) suspended from a tripod $2.2 \mathrm{~m}$ in height. A plant was placed in a basket suspended from a load cell by small galvanized chains. Load cells were connected to a system of multiplexers (AM-32 and AM-416; Campbell Scientific, Logan, UT) and a data logger (CR-10; Campbell Scientific) that measured and recorded individual mass changes every half hour. Each plant was irrigated at $0100 \mathrm{HR}$ using a single-spray stake $\left(26.6 \mathrm{~L} \cdot \mathrm{h}^{-1}\right.$; Roberts Irrigation Products, San Marcos, CA). Plants were irrigated to supersaturate the substrate each night for three nights before the experiment began.

After irrigation on 21 Oct., nightly irrigation was suspended and an initial maximum container mass was recorded at $0500 \mathrm{HR}$ for each plant. This allowed time for excess water to drain. Each plant was then allowed to transpire to the point of leaf wilt, at which point it was harvested the next morning within $1.5 \mathrm{~h}$ of sunrise. Leaf wilt was defined as leaves on three or more branches drooping by 1000 to 1200 HR. Shoots on all plants were mature and all buds were dormant throughout data collection. Just before shoot harvest, lysimeter mass was recorded $\left(\mathrm{LM}_{\text {wilt }}\right)$. The shoot was then removed at the substrate surface and wilted mass of the shoot $\left(\right.$ Shoot $\left._{\text {wilt }}\right)$ determined immediately using an electronic balance (PB5001; Mettler, Mettler-Toledo, Switzerland). Plant shoots were then dried at $65{ }^{\circ} \mathrm{C}$ until a constant dry weight was obtained $\left(\right.$ Shoot $\left._{\text {dwt }}\right)$. Once a shoot was harvested, a spray stake was returned to a container and nightly irrigation resumed. After the last plants were harvested (4 Nov.), irrigation duration was increased to resaturate all root balls within containers. By 14 Nov., all containers had exhibited a near constant mass for three or more consecutive days at $0630 \mathrm{HR}, 2.5 \mathrm{~h}$ after the last irrigation. Container mass at this time was recorded as the saturated root ball mass ( $\left.\mathrm{RB}_{\text {saturated }}\right)$.

Daily actual evapotranspiration $\left(\mathrm{ET}_{\mathrm{A}}\right)$ for each plant was determined by subtracting mass recorded for each plant at midnight by that recorded the next midnight. Daily $\mathrm{ET}_{\mathrm{A}}$ for each plant was summed to give a cumulative $\mathrm{ET}_{\mathrm{A}}$ for each plant. The difference between maximum mass the day of harvest (at midnight) and mass just before harvest was included in a cumulative $\mathrm{ET}_{\mathrm{A}}$ total.

During the drydown period, daily recordings of net solar radiation (LI-190 pyranometer; LI-COR, Lincoln, NE), maximum and minimum temperature (HMP45C; Campbell Scientific), and daily cumulative wind distance (model 014 anemometer; MetOne Instruments, Medford, OR) were recorded using a data logger (CR10; Campbell Scientific). From these, daily potential evapotranspiration $\left(\mathrm{ET}_{\mathrm{P}}\right)$ was calculated using a regional modification of the PenmanMonteith equation (Jones et al., 1984).
Calculations. Subtraction of $\mathrm{LM}_{\text {wilt }}$ from maximum hydrated lysimeter mass $\left(\mathrm{LM}_{\text {saturated }}\right)$ calculated PAW $\mathrm{W}_{\text {Total }}$ within the saturated container-plant system (Eq. 1).

$$
\mathrm{PAW}_{\text {Total }}=\mathrm{LM}_{\text {saturated }}-\mathrm{LM}_{\text {wilt }}
$$

Subtraction of resaturated root ball mass $\left(\mathrm{RB}_{\text {saturated }}\right)$ from $\mathrm{LM}_{\text {saturated }}$ calculated the shoot mass at presumably $100 \%$ relative

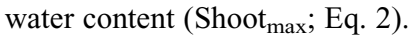

$$
\text { Shoot }{ }_{\text {max }}=\mathrm{LM}_{\text {saturated }}-\mathrm{RB}_{\text {saturated }}
$$

Shoot relative water container at wilt $\left(\mathrm{RWC}_{\text {wilt }}\right)$ was calculated as follows (Eq. 3):

$$
\begin{aligned}
\mathrm{RWC}_{\text {wilt }}= & \left(\text { Shoot }_{\text {wilt }}-\text { Shoot }_{\text {dwt }}\right) \div \\
& \left(\text { Shoot }_{\text {max }}-\text { Shoot }_{\text {dwt }}\right)
\end{aligned}
$$

where Shoot $_{\text {wilt }}$ is shoot mass at wilt, Shoot $_{\text {dwt }}$ is the shoot dry weight, and Shoot $_{\max }$ was calculated from Eq. 2 .

To evaluate the method to determine PAW in situ, daily $\mathrm{ET}_{\mathrm{A}}$ was normalized by dividing each day's $\mathrm{ET}_{\mathrm{A}}$ by the corresponding $\operatorname{ET}_{\mathrm{P}}$ (Eq. 4). This calculated a normalized $\mathrm{ET}_{\mathrm{A}}\left(\mathrm{ET}_{\mathrm{Amm}}{ }^{-1}\right)$ with the units of $\mathrm{mL} \cdot \mathrm{mm}^{-1}$ $\mathrm{ET}_{\mathrm{P}}$.

$$
\mathrm{ET}_{\mathrm{Amm}}{ }^{-1}{ }_{i}=\mathrm{ET}_{\mathrm{A} i} \div \mathrm{ET}_{\mathrm{P} i}
$$

Normalized $\mathrm{ET}_{\mathrm{A}}$ on the first day of the dry down was then used as a divisor to calculate the percent reduction in normalized $\mathrm{ET}_{\mathrm{A}}$ (\%Max $\mathrm{ET}_{\mathrm{A}}$; Eq. 5) for each day of the drydown until plant wilt. For each day, the corresponding cumulative $\mathrm{ET}_{\mathrm{A}}\left(\Sigma \mathrm{ET}_{\mathrm{A}}\right)$ was also calculated. The $\Sigma \mathrm{ET}_{\mathrm{A}}$ at the time of shoot harvest was considered to be the total PAW ( $\left.\Sigma E_{\text {ATotal }}\right)$. For each plant, a plot of $\% \operatorname{Max} \mathrm{ET}_{\mathrm{A}}$ as a function of $\Sigma \mathrm{ET}_{\mathrm{A}}$ was developed (Fig. 1). Any additional $\mathrm{ET}_{\mathrm{A}}$ between midnight and shoot harvest on a day of harvest was not included.

$$
\begin{aligned}
\% \operatorname{Max} \mathrm{ET}_{\mathrm{A}}= & \left(\mathrm{ET}_{\mathrm{A} i+1 \mathrm{~mm}}{ }^{-1} / \mathrm{ET}_{\mathrm{A} i \mathrm{~mm}}{ }^{-1}\right) \\
& \times 100
\end{aligned}
$$

where $i$ is the days after saturation of the root ball and the first day is $100 \%$ of maximum $\mathrm{ET}_{\mathrm{A}}$.

Demonstration. In Mar. 2005, rooted cuttings of $V$. odoratissimum were transplanted into 11-L containers using the same substrate formulation but supplied by a different commercial company (Florida Potting Soil, Apopka, FL). At times throughout the 13-month production period, plants were selected and placed in similar lysimeters under an open-side, single polyethylenecovered rainout shelter at the Mid-Florida Research and Education Center (Apopka, FL). After an initial saturating irrigation at midnight, $0100 \mathrm{HR}$ and $0200 \mathrm{HR}$, water was withheld and plant mass recorded every half hour for $5 \mathrm{~d}$ or until visible midmorning shoot wilt. Thereafter, containers were hand-irrigated and canopy widest width, width perpendicular to widest width, and average shoot height were recorded. These were then multiplied to calculate a canopy volume [growth
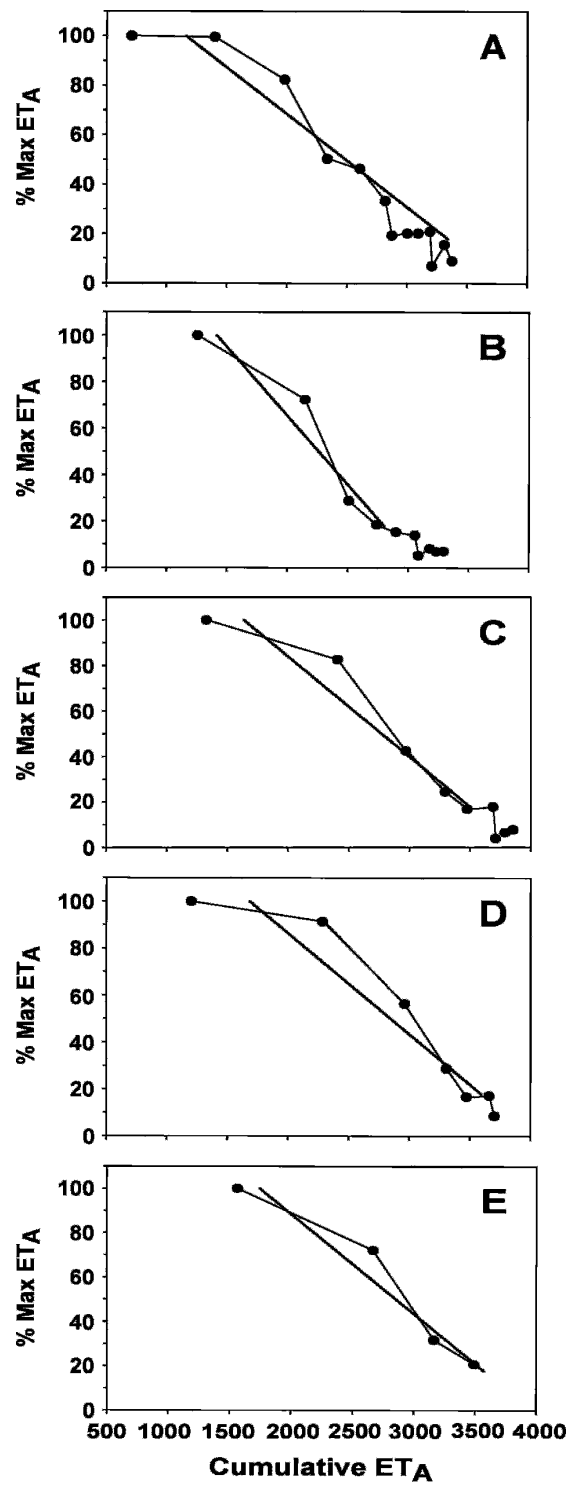

Fig. 1. Representative plots of cumulative $\operatorname{ET}_{\mathrm{A}}$ versus $\% \mathrm{MaxET}_{\mathrm{A}}$ for five species of woody ornamental plants. Species were (A) Rhaphiolepis indica, (B) Elaeagnus pungens, (C) Ligustrum japonica, (D), Photinia $\times$ fraseri, and (E) Viburnum odoratissimum. The solid line was calculated from a linear regression based on five points and $18 \%$ minimum $\% \mathrm{MaxET}_{\mathrm{A}}$.

index (GI)]. Root ball volume was measured by first carefully removing the container substrate to a point of visible root tips. The remaining undisturbed root ball was then enclosed in a polyethylene bag and root ball volume determined by volume displacement in a 19-L bucket. The bucket was set at a slight angle so that water beaded always at the lowest point on the rim. The volume of water required to return the water surface to the original, maximum bead was determined. Effective PAW was determined as described subsequently for each replication and means were calculated.

For the statistical analysis, each plant was an experimental unit. Because of malfunctions, one replication each of E. pungens and L. japonica was discarded, resulting in all nonregression analyses being conducted 
using the general linear model (GLM) in SAS (version 9.0; SAS Institute, Cary, NC). GLM was used to compare PAW $\mathrm{P}_{\text {Total }}$ as a split plot with species as the main plot and two determinations of PAW as a subplot. Similar comparison of $\mathrm{LM}_{\text {wilt }}$ and sum of $\mathrm{RB}_{\text {wilt }}+$ Shoot $_{\text {wilt }}$ were also analyzed as a split plot design with species as the main plot and methods of determination as subplots. Regression equations were calculated using SAS (PROC REG) and used to analyze relationships between $\% \mathrm{Max} \mathrm{ET}_{\mathrm{A}}$ and daily $\Sigma \mathrm{ET}_{\mathrm{A}}$. Statistics were calculated for both linear and quadratic curves using daily $\Sigma \mathrm{ET}_{\mathrm{A}}$ as an independent value. Values of total $\Sigma \mathrm{ET}_{\mathrm{A}}$ were inserted into the resulting equations to estimate \%Max $\mathrm{ET}_{\mathrm{A}}$ that occurred the day of plant wilt $\left(\%\right.$ Max $\left.\mathrm{ET}_{\text {Awilt }}\right)$. Regression was also calculated using \%Max $\mathrm{ET}_{\mathrm{A}}$ as an independent variable for the first four and five data points for each replication. GLM was then used to test the strength of four and five data point regressions to estimate total $\Sigma \mathrm{ET}_{\mathrm{A}}$ measured at plant wilt using both calculated \%Max $\mathrm{ET}_{\mathrm{A}}$ at the day of wilt and with \%Max $\mathrm{ET}_{\mathrm{A}}$ fixed at $18 \%$. The $18 \%$ was the mean minimum $\%$ MaxET $_{\mathrm{A}}$ across all species in which total $\Sigma \mathrm{ET}_{\mathrm{A}}$ measured at plant wilt was achieved. Analysis was conducted for each species independently and compared paired combinations of measured $\Sigma \mathrm{ET}_{\mathrm{A}}$ against the three estimates of $\Sigma \mathrm{ET}_{\mathrm{A}}$. Analysis of other variables of Shoot $_{\text {max }}$, Shoot wilt, $_{\text {Shoot }}$ dwt, RWC $_{\text {wilt, and }}$ $\%$ Max $\mathrm{ET}_{\mathrm{A} \mathrm{mm}}{ }^{-1}$ wilt were compared among species as a one-way analysis of variance using GLM.

\section{Results and Discussion}

Estimates of PAW were similar $(P=0.19)$ when calculated as the difference between $\mathrm{LM}_{\text {saturated }}$ and $\mathrm{LM}_{\text {wilt }}(\mathrm{PAW}$ Total , Eq. 1) and total $\Sigma \mathrm{ET}_{\mathrm{A}}$ determined by summing daily $\mathrm{ET}_{\mathrm{A}}$ (data not shown). The greatest difference between these two methods of calculation across all plants was $200 \mathrm{~g}$ or $6.01 \%$ of total $\Sigma \mathrm{ET}_{\mathrm{A}}$. Mean absolute difference among the 18 plants was $50 \mathrm{~g}$ or $1.45 \%$ of a system's $\mathrm{PAW}_{\text {Total. }}$ There was a slight tendency for total $\Sigma \mathrm{ET}_{\mathrm{A}}$ to overestimate PAW $\mathrm{P}_{\text {Total }}$ (11 of 19 plants).

Measurement of Shoot ${ }_{\text {wilt }}$ with an electronic balance was consistent with its calculation from $\mathrm{LM}_{\text {wilt }}$ at harvest. There were no differences $(P>0.9)$ between $\mathrm{LM}_{\text {wilt }}$ mass at harvest and the sum of Shoot ${ }_{\text {wilt }}$ and root ball mass at wilt $\left(\mathrm{RB}_{\text {wilt }}\right)$. The mean absolute deviation was $15 \mathrm{~g}$. There were differences $(P<0.01)$ in $\mathrm{LM}_{\text {wilt }}$ among species. However, because basket and chain mass was not recorded for each lysimeter, comparisons of absolute mass could not be made.

Shoot dry weight was significantly different among species (Table 1). Because plants were market size for 11-L containers, woody stem mass contributed the majority of Shoot ${ }_{\mathrm{dwt}}$, especially for the larger canopy species. The species with the largest Shoot ${ }_{\mathrm{dw}}$, L. japonica, $P \times$ fraseri, and $V$. odoratissimum, were all at least $0.75 \mathrm{~m}$ in height

Table 1. Mean values for components of plant mass and relative water content during determination of plant-available water. ${ }^{\mathrm{z}}$

\begin{tabular}{llcccr}
\hline Genus & $\begin{array}{c}\text { Shoot dry } \\
\text { mass }(\mathrm{g})\end{array}$ & $\begin{array}{c}\text { Shoot mass } \\
\text { at wilt }(\mathrm{g})\end{array}$ & $\begin{array}{c}\text { Shoot dry wt: } \\
\text { shoot wilt mass }\end{array}$ & $\begin{array}{c}\text { RWC at } \\
\text { shoot wilt }^{\mathrm{y}}\end{array}$ & $\begin{array}{c}\text { Saturated } \\
\text { shoot mass }(\mathrm{g})\end{array}$ \\
\hline Rhaphiolepis & $237.2 \mathrm{~b}^{\mathrm{x}}$ & $532.2 \mathrm{c}$ & $0.445 \mathrm{a}$ & $0.524 \mathrm{~d}$ & $824.3 \mathrm{~b}$ \\
Elaeagnus & $312.2 \mathrm{~b}$ & $690.0 \mathrm{c}$ & $0.452 \mathrm{a}$ & $0.783 \mathrm{~b}$ & $797.0 \mathrm{~b}$ \\
Ligustrum & $563.1 \mathrm{a}$ & $1275.0 \mathrm{ab}$ & $0.442 \mathrm{a}$ & $0.814 \mathrm{~b}$ & $1438.7 \mathrm{a}$ \\
Photinia & $506.4 \mathrm{a}$ & $1163.3 \mathrm{~b}$ & $0.446 \mathrm{a}$ & $0.667 \mathrm{c}$ & $1521.0 \mathrm{a}$ \\
Viburnum & $499.1 \mathrm{a}$ & $1455.2 \mathrm{a}$ & $0.340 \mathrm{~b}$ & $0.938 \mathrm{a}$ & $1465.7 \mathrm{a}$ \\
\hline
\end{tabular}

${ }^{\mathrm{z}}$ Genus are listed in relative order from most to least drought-tolerant in containers.

${ }^{y}$ Relative water content of a shoot the morning after midday visible wilt.

${ }^{x}$ Means with the same letter are not significantly $(P>0.05)$ different based on Fisher protected least significant difference. Means based on five replications except for Elaeagnus and Ligustrum, which were four replications.

and had comparable shoot dry weight. These three species are considered to be upright spreading shrubs (Gaskalla, 1998). Rhaphiolepis indicia was the shortest species at $\approx 0.3$ $\mathrm{m}$ with $E$. pungens height midway between the extremes.

Shoot $_{\text {wilt }}$ mass varied among species, but relative rankings were similar to that for Shoot $_{\mathrm{dwt}}$ (Table 1). V. odoratissimum, L. japonica, and $P \times$ fraseri had much greater mass, nearly double that of $E$. pungens and $R$. indicia at canopy wilt. Similarly, these same three had nearly double the estimated shoot saturated mass (Table 1). Relative ranking by mass at wilt was different from for Shoot $_{\mathrm{dwt}}$ for the three largest species. Although not significant $(P>0.05)$, V. odoratissimum had the least Shoot $_{\mathrm{dwt}}$ but $(P<$ $0.05)$ greater mass at wilt than $P \times$ fraseri (Table 1). Despite differences $(P<0.05)$ among species in both Shoot ${ }_{\mathrm{dwt}}$ and Shoot ${ }_{\mathrm{wilt}}$, ratios of Shoot $_{\text {dwt }}:$ Shoot $_{\text {wilt was }} 0.44 \pm 0.01$ for all species except $V$. odoratissimum with a ratio of 0.34 (Table 1 ). This ratio was consistent across most species, although there were substantial differences in plant size and observational responses to water stress. Thus, when water content of a shoot of most plants evaluated declined to $\approx 2.25$ times Shoot $_{\mathrm{dwt}}$, a plant was visibly wilted. For $V$. odoratissimum, generally considered least tolerant of water stress in containers, visible wilt occurred with at a higher level of tissue water content. Mean $\mathrm{RWC}_{\text {wilt }}$ of $V$. odoratissimum of $93.8 \%$ was higher than that of other species (Table 1). With the exception of $L$. japonica and E. pungens, $\mathrm{RWC}_{\text {wilt }}$ was unique and different $(P<0.05)$ among all species, although Shoot $_{\text {dwt }}:$ Shoot $_{\text {wilt }}$ ratios were consistent. Water in the xylem likely contributed substantially to plant mass at wilt and is likely the reason for different $\mathrm{RWC}_{\text {wilt }}$ among species. This difference in $\mathrm{RWC}_{\text {wilt }}$ accounts for the higher Shoot ${ }_{\text {wilt }}$ for $V$. odoratissimum than $P \times$ fraseri relative to their Shoot $_{\mathrm{dwt}}$. Importance and significance of the Shoot $_{\mathrm{dwt}}:$ Shoot $_{\text {wilt }}$ ratio is unknown and may deserve further investigation.

$\mathrm{RWC}_{\text {wilt }}$ was not predictable from other shoot measurements such as Shoot ${ }_{\mathrm{dwt}}$, Shoot $_{\text {wilt }}$, or ratios of these two. Of these species, V. odoratissimum is considered to have low drought tolerance in containers, whereas $R$. indica is considered to be very tolerant. The relative order of $\mathrm{RWC}_{\text {wilt }}$ appears reasonable. Previously, Beeson (1992) suggested water potential thresholds for stomatal closure for L. japonica and E. pungens were similar with E. pungens being somewhat more drought-tolerant. However, the lower $\mathrm{RWC}_{\text {wilt }}$ for $P . \times$ fraseri is opposite of what would have been expected based on previous reported stomata thresholds. These differences in $\mathrm{RWC}_{\text {wilt }}$ suggest a possible quick way to screen landscape shrub species for drought tolerance.

Normalized values of $\mathrm{ET}_{\mathrm{A}}$ the first day of the drydown were always highest independent of plant species or replication. As days without irrigation progressed, $\mathrm{ET}_{\mathrm{A}}$ normalized by $\mathrm{ET}_{\mathrm{P}}$ declined, resulting in continuous declines in $\% \mathrm{MaxET}_{\mathrm{A}}$ for at least the first 4 to $5 \mathrm{~d}$ of the drydown (Fig. 1). After $\approx 5 \mathrm{~d}$, declines in $\% \mathrm{MaxET}_{\mathrm{A}}$ slowed and became variable for some species (Fig. 1A-B). This variability became more conspicuous as duration of the drydown increased as exemplified by $R$. indica (Fig. 1A). However, for $V$. odoratissimum, canopy wilt was achieved within a 4- to 5-d timeframe (Fig. 1E). For all plants of the other species, 7 to $14 \mathrm{~d}$ was required until visible wilt was observed. This long duration resulted from both all plant tissue being mature and relatively low $\mathrm{ET}_{\mathrm{P}}$ that occurred during the drydown period. $\mathrm{ET}_{\mathrm{P}}$ ranged from 1 to $3.7 \mathrm{~mm}$ daily with a median value of $3.3 \mathrm{~mm}$.

Regression analysis was applied to all data sets to calculate $\% \mathrm{MaxET}_{\mathrm{A}}$ as a function of $\Sigma \mathrm{ET}_{\mathrm{A}}$ to determine the best fit relationship between the two variables. Because there were no differences between $\Sigma \mathrm{ET}_{\mathrm{ATotal}}$ and $\mathrm{PAW}_{\text {Total, }}$, daily $\Sigma \mathrm{ET}_{\mathrm{A}}$ is representative of cumulative daily water loss from a plantsubstrate system over time. Some plots, particularly those of $P . \times$ fraseri, suggested a quadratic relationship between $\Sigma E_{\mathrm{A}}$ and $\% \mathrm{MaxET}_{\mathrm{A}}$ (Fig. 1D), thus, regression analysis was calculated for both linear and quadratic curves for each replication. Correlation coefficients $\left(r^{2}\right)$ were similar between linear and quadratic equations for most replications (data not shown). Values for $\mathrm{r}^{2}$ ranged from 0.849 to 0.976 . Quadratic equations increased the $\mathrm{r}^{2}$ value by $5 \%$ to $11 \%$ for three of the four $P . \times$ fraseri (average $\mathrm{r}^{2}=0.882$ linear to 0.961 quadratic) and by $6 \%$ for one $R$. indica replication. Quadratic terms were not significant $(P>0.5)$ for V. odoratissimum. 
Values of $\Sigma \mathrm{ET}_{\mathrm{ATotal}}$ were inserted into both linear and quadratic equations derived to compare $\% \mathrm{MaxET}_{\mathrm{A}}$ estimated by these lines with $\% \mathrm{MaxET}_{\mathrm{A}}$ derived from the last day of the drydown $\left(\% \mathrm{MaxET}_{\text {Awilt }}\right)$ for each replication. Comparing \% $\mathrm{MaxET}_{\text {Awilt }}$ with calculated values found little difference between values generated by linear or quadratic equation (data not shown). Linear equations tended to be more accurate in predicting $\% \mathrm{MaxET}_{\text {Awilt }}$ than quadratic equations (data not shown). Thus, for simplicity and accuracy, only linear equations were carried forward.

Having established a linear relationship between $\% \mathrm{MaxET}_{\mathrm{A}}$ and $\Sigma \mathrm{ET}_{\mathrm{A}}$, the next step in establishing a method to estimate in situ PAW $_{\text {Effec }}$ was to define the relationship

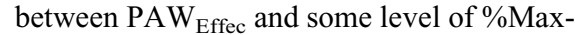
$\mathrm{ET}_{\mathrm{A}}$. For all species except $V$. odoratissimum, a linear decline in $\% \mathrm{MaxET}_{\mathrm{A}}$ with increasing $\Sigma \mathrm{ET}_{\mathrm{A}}$ was followed by a pronounced slowing of that decline, either linearly or with oscillating variability (Fig. 1). The initial linear decline is proposed to be a direct result of gradual stomata closure resulting from decreases in available water within access of a root system. Gradual stomatal closure would reduce transpiration while drying of the substrate surface would reduce evaporation (Kramer and Boyer, 1995). The abrupt deviation in the linear decline is proposed to be the result of stomata closure. Thereafter, water lost would be mainly through cuticular transpiration and substrate evaporation. Because there is little to no photosynthesis with stomatal closure of most temperate woody plants, it is proposed that PAW at this point is essentially the $\mathrm{PAW}_{\text {Effec. }}$ Although a plant may or may not exhibit wilt at this point, its net carbon balance would be near zero or less. In production situations in which the objective is growth, complete stomata closure is unacceptable. Thus, the minimum $\% \mathrm{MaxET}_{\mathrm{A}}$ was sought where $\mathrm{PAW}_{\mathrm{Effec}}$ was achieved. Plots of $\% \mathrm{MaxET}_{\mathrm{A}}$ versus $\Sigma \mathrm{ET}_{\mathrm{A}}$ were visually examined for all plants to determine $P A W_{\text {Effec }}$. These were then inserted into the linear equations derived and $\% \mathrm{MaxET}_{\mathrm{A}}$ calculated. Mean minimum $\%$ MaxET $_{\mathrm{A}}$ across all species was $18 \%$ (Fig. 1). Individual plant values ranged from $15.0 \%$ to $21.8 \%$.

The final step was to determine the minimum number of days of a drydown required for accurate calculation of $\mathrm{PAW}_{\mathrm{Effec}}$. Using $18 \%$ as $\% \mathrm{MaxET}_{\mathrm{A}}$ and linear regression lines calculated from the first 4 and $5 \mathrm{~d}$ of a drydown, $\Sigma \mathrm{ET}_{\mathrm{A}}$ was calculated for both regression equations for each plant. These values of estimated $\Sigma \mathrm{ET}_{\mathrm{A}}$ were compared with actual measured $\Sigma \mathrm{ET}_{\mathrm{A}}$ and $\Sigma \mathrm{ET}_{\mathrm{A}}$ calculated with each plant's actual $\% \mathrm{MaxET}_{\mathrm{A}}$ at $\mathrm{PAW}_{\mathrm{Effec}}$. Overall, estimates from regressions based on $5 \mathrm{~d}$ of drydown were more accurate than those based on $4 \mathrm{~d}$ (data not shown). However, the gain in accuracy was generally small, from near $0 \%$ to $5 \%$. On both a species basis and among species, there were no differences $(P>0.05)$ between $\Sigma \mathrm{ET}_{\mathrm{A}}$ estimated from the first $5 \mathrm{~d}$ of the drydown using $18 \%$ as $\%$ MaxET $_{\mathrm{A}}$ or estimated from the actual $\%$ MaxET $_{\mathrm{A}}$. Similarly, both these estimates of $\Sigma \mathrm{ET}_{\mathrm{A}}$ were not different $(P>$ 0.05 ) from measured values. Errors using $18 \%$ as $\% \mathrm{MaxET}_{\mathrm{A}}$ were between near $0 \%$ and $6 \%$ with an average error of $2.5 \%$ compared with measured values.

Using a 4-d drydown, overall, there were no differences $(P>0.05)$ between estimated $\Sigma \mathrm{ET}_{\mathrm{A}}$ using 18 as $\% \mathrm{MaxET}_{\mathrm{A}}$ or actual $\%$ MaxETA and measured values. Estimates of $\Sigma \mathrm{ET}_{\mathrm{A}}$ based on 18 as $\% \mathrm{MaxET}_{\mathrm{A}}$ and a four-point curve had a mean error from the measured $\Sigma \mathrm{ET}_{\mathrm{A}}$ of $3.9 \%$ and ranged from near $0 \%$ to $8.2 \%$. Thus, for species evaluated, a 5-d drydown was sufficient for an accurate estimate of PAW $\mathrm{Effec}_{\text {and mostly avoided }}$ pushing plants into a wilted state. However, with reference evapotranspiration $\left(\mathrm{ET}_{0}\right)$ greater than $4.5 \mathrm{~mm}$ and plants two-thirds grown or better, where declines in PAW occur more quickly than in this experiment, a 4-d drydown would be acceptable and preferred.

To demonstrate changes in $\mathrm{PAW}_{\mathrm{Effec}}$ during a production cycle, data were extracted from an experiment using $V$. odoratissimum grown from rooted cuttings (30052202 Jiffy Strips; Jiffy Products of America, Norwalk, $\mathrm{OH}$ ) in an 11-L container. A month after transplanting in the 11-L container, root exploration into the substrate was approximately one-fourth the total container volume. However, mean $\mathrm{PAW}_{\mathrm{Effec}}$ of $0.51 \mathrm{~L}$ was $\approx 17 \%$ of $\mathrm{PAW}_{\text {Total }}$ of a root ball at full container volume (Fig. 2). Roots generally had not reached the side walls at this point, but were growing in a wide cone shape downward. This illustrates the increasing gradient of the PAW of this substrate from top to bottom of the substrate column. Canopy volume was $1526 \mathrm{~cm}^{3}, 0.4 \%$ of that of harvested plants (Fig. 2). Three months later, $\mathrm{PAW} \mathrm{Effec}_{\mathrm{p}}$ had almost doubled to $\approx 32 \%$ of PAW $_{\text {Total }}$ with the root ball volume extending to approximately half the available container volume. Canopy volume had doubled to $3899 \mathrm{~cm}^{3}$, but still only $\approx 1 \%$ of the harvested canopy. Although canopies were visually developing at a good rate, root growth was much more rapid, expanding into virgin PAW. At 109 d after transplanting, root ball volume was roughly $25 \%$ larger than shoot volume in this substrate blend. Based on observations since 1990, root ball to canopy volume is more dependent on PAW than physical volume (unpublished data). Irrigation managers should take advantage of this greater increase in PAW than canopy volume, conserving irrigation for later in the production when daily $\mathrm{ET}_{\mathrm{A}}$ can reach one-third of $\mathrm{PAW}_{\text {Total }}$ (data not shown). Seven months after transplanting (day 232), PAW $_{\text {Effec }}$ had tripled to $3.1 \mathrm{~L}$, although physical root ball volume had only increased $\approx 20 \%$ over the same period. At this point, root systems had not completely engulfed the substrate with the containers, but a few roots were at the bottom of the root ball. Canopy volume, however, increased 5.8-fold to $0.026 \mathrm{~m}^{3}$ over the same period. With the drydown at harvest 13 months after transplanting, PAW $\mathrm{P}_{\text {Total }}$ was the same $(P>0.05)$ as that calculated at 7 months, although root ball volume had increased $\approx 30 \%$ to completely encompass the substrate volume. Correspondingly, canopy volume had increased nearly 12 -fold to $0.34 \mathrm{~m}^{3}$.

PAW $_{\text {Total }}$ for $V$. odoratissimum measured at harvest was not as great as that measured in 1997 nor was it consistent with PAW Total of the other species in similar containers (Table 2). There are several possible reasons for this. In 2006, plants at harvest were

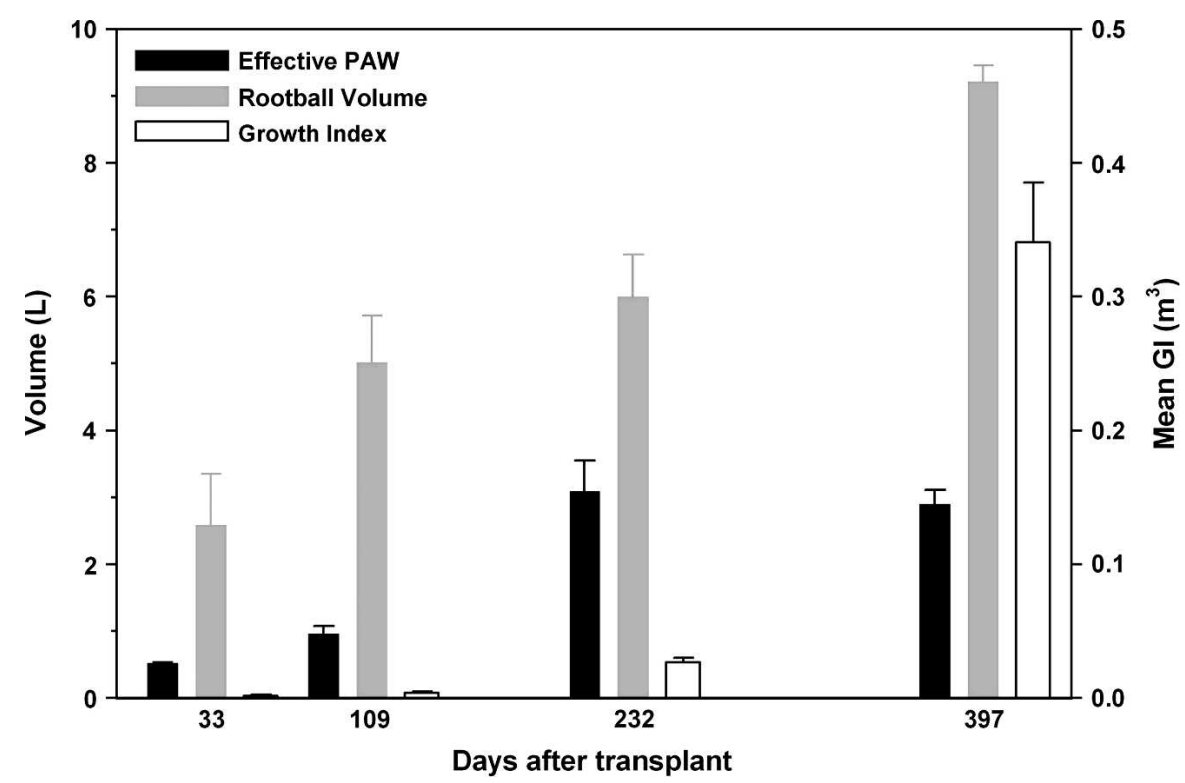

Fig. 2. Measured values of effective plant-available water $\left(\mathrm{PAW}_{\mathrm{Effec}}\right)$, root ball volume, and shoot volume (growth index) of Viburnum odoratissimum grown from rooted cuttings to market-sized plants. Plants were of market size and harvested at day 397. Means represent four to seven plant replications, depending on time after transplanting. Error bars represent the SD. 
Table 2. Total plant-available water $\left(\mathrm{PAW}_{\text {Total }}\right)$ based on cumulative $\mathrm{ET}_{\mathrm{A}}\left(\sum \mathrm{ET}_{\mathrm{A}}\right)$ for the five species from the 1997 experiment and for the $V$. odoratissimum taken from the 2005 to 2006 experiment. $^{\mathrm{z}}$

\begin{tabular}{ll}
\hline Species & \multicolumn{1}{c}{ Mean } \\
Rhaphiolepis indica & $\mathrm{PAW}_{\text {Total }}(\mathrm{L})$ \\
Elaeagnus pungens & $3.444 \pm 0.165$ \\
Ligustrum japonica & $3.357 \pm 0.177$ \\
$\begin{array}{l}\text { Photinia } \times \text { fraseri } \\
\text { Viburnum odoratissimum }\end{array}$ & $3.551 \pm 0.45$ \\
Viburnum & $3.434 \pm 0.166$ \\
$\quad$ odoratissimum-2005-2006 & $2.898 \pm 0.212$ \\
\hline
\end{tabular}

${ }^{\mathrm{z}}$ Genus are listed in relative order from most to least drought-tolerant in containers. The $\pm \mathrm{SD}$ is based on four (Ligustrum, Elaeagnus), nine (2005-2006 Viburnum), or five (remaining species) replications.

overhead-irrigated normally and the root balls were likely not fully saturated as they were with excessive microirrigation in 1997 or as they were in previous measurements in 2005. This is the most probable explanation because PAW at harvest was the same as that at 7 months, although root ball volume at 7 months was not at the maximum as it was at the harvest. Additionally, harvested plants in 2006 were smaller that those used in 1997 as evident by the smaller $(P<0.05)$ dry weight (272.4 g versus $499.1 \mathrm{~g})$. This would have lowered the amount of PAW derived from woody stem tissue.

Through applying this procedure many times since its inception, there are two conditions that are critical to its successful use. One, the first day of a drydown must be one that has the best chance of having an average or higher reference $\mathrm{ET}_{0}$ for the region and season. Midday rain and prolonged cloudiness the first day, followed by a mostly sunny day resulting in higher $\mathrm{ET}_{0}$, can shift the day of maximum $\mathrm{ET}_{\mathrm{A}}$ to the second day, damaging the correlation of $\% \mathrm{MAXET}_{\mathrm{A}}$ with $\Sigma \mathrm{ET}_{\mathrm{A}}$. This is more critical the less time a plant has been in a container with uncolonized substrate. Should low $\mathrm{ET}_{0}$ conditions occur after the first day, consequences are less severe. The other critical item, as was seen in the 2006 harvest results, is to thoroughly saturate a root ball initially to be able to determine an accurate volume of PAW.
Results suggest that determining $\mathrm{RWC}_{\text {wilt }}$ could be used to rapidly screen plant species for drought tolerance. Lower $\mathrm{RWC}_{\text {wilt }}$ suggests an indicative tolerance of a species to water stress, which could be verified by pressure-volume curve analysis (Tyree and Hammel, 1972). Evaluation of this hypothesis using established in-ground plants appears warranted. From a practical perspective, quantification of $\mathrm{PAW}_{\mathrm{Effec}}$ results in more accurate characterization of deficit irrigation on plants growth in containers. It can also be used to quantify root growth in containers nondestructively and repeatedly. In nursery production, $\mathrm{PAW} \mathrm{Effec}_{\mathrm{C}}$ could be determined every 4 to 6 weeks over a 5 -d period with mass recorded before dawn each day. Measurement the fifth morning would provide the four minimum points to generate the linear regression curve with $\mathrm{PAW}_{\mathrm{Effec}}$ calculated using $18 \% \mathrm{MaxET}_{\mathrm{A}}$. With experience, irrigation managers could determine $\mathrm{PAW}_{\mathrm{Effec}}$ relative to container water capacity. Applying principles of deficit irrigation, irrigation would be frequent and light after transplanting, progressing rapidly to less frequent and greater volume as roots explore the substrate. This would result in less nutrient leaching and greater capture of rainfall. Irrigation in excess of PAW, especially for young crops, wastes water and energy and promotes excessive leaching of nutrients from a substrate. The main limitation with this method is the need for accurate calculation of daily $\mathrm{ET}_{0}$. Although some states have this available through the Internet, in states like Florida where cloud cover can be sporadic, a good onsite weather station would be preferred. These results from market-sized plants suggest PAW Total $_{\text {is more an effect of container }}$ geometry and substrate composition and physical properties than plant species. Differences in root growth and growth direction would influence the rate at which $\mathrm{PAW}_{\mathrm{Effec}}$ increases with time.

\section{Literature Cited}

Beardsell, D.V., D.G. Nichols, and D.L. Jones. 1979a. Physical properties of nursery pottingmixtures. Sci. Hort. 11:1-8.

Beardsell, D.V., D.G. Nichols, and D.L. Jones. 1979b. Water relations of nursery pottingmedia. Sci. Hort. 11:9-17.
Beeson R.C., Jr. 1992. Restricting overhead irrigation to dawn limits growth in containergrown woody ornamentals. HortScience. 27: 996-999.

Beeson R.C., Jr. 2006. Relationship of plant growth and actual evapotranspiration to irrigation frequency based on managed allowable deficits for container nursery stock. J. Amer. Soc. Hort. Sci. 131:140-148.

Beeson R.C., Jr. and T.H. Yeager. 2003. Plant canopy affects sprinkler application efficiency of container-grown ornamentals. HortScience 38:1373-1377.

Bilderback, T.E. and W.C. Fonteno. 1987. Effects of container geometry and media physical properties on air and water volumes in containers. J. Environ. Hort. 5:180-182.

Bilderback, T.E., W.C. Fonteno, and D.R. Johnson. 1982. Physical properties of media composed of peanut hulls, pine bark, and peatmoss and their effects on azalea growth. J. Amer. Soc. Hort. Sci. 107:522-525.

Bunt, A.C. 1976. Modern potting compost. The Pennsylvania State Univ. Press, University Park, PA.

Davis, W.D., S.T. Besemer, and D.H. Close 1964. Landscaping in planters without natural drainage. U.C. Agr. Ext. Serv. AXT 124:1-13.

Jones, J.W., L.H. Allen, S.F. Shih, J.S. Rogers, L.C Hammond, A.G. Smajstrala, and J.D. Martsolf. 1984. Estimated and measured evapotranspiration for Florida climate, crops and soils. Ag. Exp. Station, Instit. Food and Agric Sci. Univ. of Florida. Bulletin 840.

Gaskalla, R. Director Division of Plant Industry. 1998. Grades and standards for nursery plants, 2nd ed. Florida Dept. of Agr. and Consumer Services. Tallahassee, FL. p. 237.

Kramer, P.J. and J.S. Boyer. 1995. Water relations of plants and soils. Academic Press, Inc., San Diego. CA.

Richards, D., M. Lane, and D.V. Beardsell. 1986. The influence of particle-size distribution in pinebark:sand:brown coal potting mixes on water supply, aeration and plant growth. Sci. Hort. 29:1-14.

Spooner, L.A. 1974. Two classroom exercises demonstrating the pattern of container soil water distribution. HortScience 9:152-153.

Tyree, M.T. and H.T. Hammel. 1972. The measurement of turgor pressure and the water relations of plants by the pressure-bomb technique. J. Expt. Bot. 23:267-282.

Welsh, D.F. and J.M. Zajicek. 1993. A model for irrigation scheduling in container-grown nursery crops utilizing management allowed deficit (MAD). J. Environ. Hort. 11:115-118.

Williams, D.J. 1978. Handling plants in containers. J. Arbor. 4:184-186. 